\title{
Temperature Management in Stroke - an Unsolved, but Important Topic
}

\author{
Bernd Kallmünzer Rainer Kollmar \\ Department of Neurology, University of Erlangen-Nürnberg, Erlangen, Germany
}

\section{Key Words}

Hypothermia $\cdot$ Fever $\cdot$ Stroke $\cdot$ Ischemia

\begin{abstract}
Clinical data clearly show that elevated body temperature contributes to an unfavorable outcome after ischemic and hemorrhagic stroke. Two promising therapeutic strategies arise from this observation: (1) treatment of fever aiming to sustain normothermia and (2) induced hypothermia, targeting core body temperatures below $36.5^{\circ} \mathrm{C}$. A limited number of studies investigated antipyretic strategies after acute stroke and their results were rather disappointing in terms of clinical efficacy. For that reason, it remains unproven, whether sufficient fever treatment improves functional outcome. On the other hand, strong experimental evidence supports neuroprotective effects of induced hypothermia after stroke. Yet, clinical data on this topic remain preliminary and rely on a limited number of patients, mostly enrolled in nonrandomized trials. Therefore, induced hypothermia may be considered safe and feasible after ischemic stroke, but little can be said regarding efficacy. This review summarizes the data, both on fever treatment and induced hypothermia following stroke, starting with a synopsis of the most important experimental investigations, leading to the latest clinical trials. Given the promising data and the lack of successful acute neuroprotective therapies available thus far, suggestions are given for future investigation on both topics.
\end{abstract}

Copyright $\odot 2011$ S. Karger AG, Basel

\section{KARGER}

Fax +4161306 1234 E-Mail karger@karger.ch www.karger.com

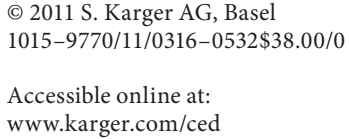

\section{Background}

Stroke is the second leading cause of death worldwide and the leading cause of disability in high-income countries. The increase of the world's population and its increasing longevity portend an enormous socioeconomic problem for the future [1]. In contrast, therapeutic options are disillusioning at present and no effective treatments are available for hemorrhagic stroke other than blood pressure control and management of secondary effects. In patients with acute ischemic stroke, the early use of antithrombotic therapy [2], intravenous thrombolysis $[3,4]$ and intra-arterial clot retrieval remain the only established acute therapies [5]. Two devices for clot retrieval are FDA approved at present $[6,7]$. However, many patients are ineligible for this approach or may not benefit from its use despite heroic attempts. New, innovative modalities of treatment of acute ischemic stroke are desperately needed.

Recent guidelines $[8,9]$ recommend antipyretic treatment for stroke patients based on the association between increased body temperature and poor neurological outcome $[10,11]$. However, there are no precise recommendations on the methods for fever control, pharmacological or mechanistic, due to a lack of clinical evidence. This is contrary to the robust experimental data, suggesting multiple modes of neuroprotection mediated by temperature control in various animal models of acute brain in- 
jury. Moreover, therapeutic hypothermia is apparently the only neuroprotective method to show a successful transfer from bench to bedside [12], since two milestone publications demonstrated a higher survival rate and improved neurological outcome after cardiac arrest with the use of induced hypothermia $[13,14]$.

\section{Evidence for the Influence of Increased Body Temperature in Stroke}

\section{Experimental Studies}

Increased body and brain temperatures influence the pathophysiologic cascade after acute brain injury by different pathways, including increased levels of excitatory amino acids (e.g. glutamate and dopamine), free radicals, lactic acid and pyruvate; increases in ischemic depolarization; blood-brain barrier breakdown; impaired enzymatic function, and reduced cytoskeletal stability [15]. These events may lead to cerebral edema, reduce cerebral perfusion pressure and secondarily lead to larger volumes of ischemic injury. In varied stroke subtypes, including ischemic stroke, subarachnoid hemorrhage, and intracerebral hemorrhage, these effects were observed in different intensities [16]. In rodents, external warming resulted in aggravated neuronal damage after global ischemia, substantiating the causal contribution of elevated body temperature to worse functional outcome at least in animal models $[17,18]$.

\section{Clinical Studies}

A meta-analysis demonstrated the association of fever/elevated body temperature with poor outcome across multiple outcome measures, using 39 clinical studies covering 14,431 patients with stroke and other brain injuries [10]. Elevated body temperature was significantly associated with worse outcome as indicated by higher mortality rates, greater disability, more dependence, worse functional outcome, greater disease severity and longer stays in the hospital and intensive care unit (ICU). The size of the effect ranged in different studies from moderate to small ( 0.26 for scores on the Glasgow Outcome Scale) to large [over 0.8 for the modified Ranking Scale (mRS)]. However, in contrast to preclinical data, a causal link between body temperature and outcome after stroke cannot be derived from these studies, as fever may represent an epiphenomenon of cerebral injury.

Notably, $67 \%$ of the hemorrhagic stroke studies and all ischemic stroke studies evaluated the results of temperatures taken on admission or within the first $24 \mathrm{~h}$. This underlines in particular the importance of the first few hours. However, experimentally described secondary delayed injury after stroke due to inflammation and apoptosis suggests the potential impact of elevated body temperature beyond the first days. Clinical studies of a more protracted course of fever including the first weeks after stroke onset should be undertaken in the future to identify the therapeutic time window for therapeutic interventions.

\section{Treatment of Increased Body Temperature after Stroke}

\section{Experimental Studies}

While the association of hyperthermia and unfavorable outcome after stroke is very well established in animal models, the exclusive impact of symptomatic antipyretic treatment has rarely been studied [19]. Therefore, no reliable preclinical data substantiate the usage of clinically established treatments, such as antipyretics like paracetamol or metamizole, after stroke. This lack may be due to a deficiency in appropriate animal models leading to predictable increases in body and brain temperatures.

\section{Clinical Trials on Fever Treatment after Stroke}

Extensive research on fever treatment in stroke patients should follow the aforementioned association between fever and clinical outcome. However, a meta-analysis demonstrated the current limitation of data [20]. Only five prospective, controlled studies reached the scientific level to be included. Since then, results from a large phase 3 clinical trial on medical treatment [21] and a prospective controlled trial using endovascular cooling [22] have become available.

Pharmacological Treatment Studies

Table 1 summarizes important prospective, controlled pharmacologic treatment studies on fever, performed during the past 10 years. Their design was rather simple. Dippel et al. [23] investigated 75 patients treated with paracetamol (1,000 or $500 \mathrm{mg})$ or placebo as a suppository, 6 times daily for 5 days. Koennecke and Leistner [24] administered paracetamol 1,000 mg or placebo orally 4 times daily for 5 days to 44 participants. Kasner et al. [73] exclusively treated 39 patients during the early phase after stroke onset $(24 \mathrm{~h})$ with $4,550 \mathrm{mg}$ oral paracetamol versus placebo. Either paracetamol 1,000 $\mathrm{mg}$ or ibuprofen $400 \mathrm{mg}$ (orally or as a suppository) ver- 
Table 1. Prospective, randomized trials on pharmacologic antipyretic treatment of patients with acute stroke

\begin{tabular}{|c|c|c|c|c|c|c|c|c|c|}
\hline $\begin{array}{l}\text { Reference, } \\
\text { year }\end{array}$ & Intervention & $\mathrm{n}$ & Disease & $\begin{array}{l}\text { Blind- } \\
\text { ing }\end{array}$ & $\begin{array}{l}\text { Number } \\
\text { of study } \\
\text { centers }\end{array}$ & $\begin{array}{l}\text { Qualifying } \\
\text { body tem- } \\
\text { perature, }{ }^{\circ} \mathrm{C}\end{array}$ & $\begin{array}{l}\text { Duration } \\
\text { of treat- } \\
\text { ment, days }\end{array}$ & $\begin{array}{l}\text { Measure- } \\
\text { ment }\end{array}$ & $\begin{array}{l}\text { Temperature reduction vs. } \\
\text { control }(24 \mathrm{~h}),{ }^{\circ} \mathrm{C}\end{array}$ \\
\hline $\begin{array}{l}\text { Koennecke and } \\
\text { Leistner [24], } 2001\end{array}$ & paracetamol 4 g/day (oral) & 44 & IS & 1 & 1 & $<37.5$ & 5 & tympanic & n.p. \\
\hline $\begin{array}{l}\text { Kasner } \\
\text { et al. [73], } 2002\end{array}$ & paracetamol 4,550 mg (oral) & 39 & IS, ICH & $1 ; 2$ & 2 & $<38.5$ & 24 & bladder & $\begin{array}{l}0.22 \\
(95 \% \mathrm{CI}-0.08 \text { to } 0.51)\end{array}$ \\
\hline $\begin{array}{l}\text { Dippel } \\
\text { et al. [25], } 2003\end{array}$ & $\begin{array}{l}\text { paracetamol } 6 \mathrm{~g} / \text { day or ibuprofen } \\
2,400 \mathrm{mg} / \text { day (oral or rectal) }\end{array}$ & 151 & IS & 2 & 3 & $36-39$ & 5 & $\begin{array}{l}\text { rectal/ } \\
\text { tympanic }\end{array}$ & $\begin{array}{l}0.27 \\
(95 \% \text { CI } 0.05-0.48)\end{array}$ \\
\hline $\begin{array}{l}\text { Castillo et al. } \\
\text { [unpubl.], } 2003\end{array}$ & metamizole $6 \mathrm{~g} /$ day (oral) & 60 & IS & 2 & 1 & $37-38$ & 3 & tympanic & n.p. \\
\hline $\begin{array}{l}\text { Den Hertog } \\
\text { et al. [20], } 2009\end{array}$ & $\begin{array}{l}\text { paracetamol } 6 \mathrm{~g} / \text { day } \\
\text { (oral/rectal) }\end{array}$ & 1,400 & IS, ICH & 2 & 29 & $36-39$ & 3 & $\begin{array}{l}\text { tympanic/ } \\
\text { rectal }\end{array}$ & $\begin{array}{l}0.26 \\
(95 \% \text { CI } 0.18-0.31)\end{array}$ \\
\hline
\end{tabular}

$\mathrm{n}=$ Number of patients enrolled; IS = ischemic stroke; $\mathrm{ICH}=$ intracerebral hemorrhage; $\mathrm{n} . \mathrm{p} .=$ not provided. Blinding: $1=$ single blind; $2=$ double blind.

sus placebo was administered to 75 participants 6 times daily for 5 days in a trial by Dippel et al. [25]. Castillo et al. [original data unpubl.; see also ref. 20] gave metamizole 2,000 mg 3 times daily for 3 days. Neither one single study, nor the analysis of their pooled data showed a significant impact on death or dependency. The multicenter, placebo-controlled PAIS trial [21] followed these small studies. 1,400 patients with acute ischemic stroke or intracerebral hemorrhage were enrolled within 5 years in 29 Dutch study centers and received either a daily dose of 6 g paracetamol for 3 days or placebo. Only $70 \%$ of the patients completed the full treatment period. The mean body temperature at $24 \mathrm{~h}$ from treatment onset was $0.26^{\circ} \mathrm{C}$ (95\% CI $0.18-0.31$ ) lower in the active than in the placebo group, but no significant difference was seen in the number of patients with improvement beyond expectation on the mRS after 3 months. Interestingly patients in the PAIS trial with fever at baseline (37$39^{\circ} \mathrm{C}$ ) had a better outcome with paracetamol. This finding, although not derived from a predefined endpoint, may be crucial for the interpretation of these studies. It underlines the high importance to carefully define a qualifying body temperature, from which on treatment may be initiated. However, prophylactic treatment with high doses of antipyretic medication in the absence of fever may be an inadequate approach. It lowered the effect size in clinical studies and may have prevented or retarded the diagnosis and workup of ongoing infections.
Physical Treatment Studies

Promising strategies for physical treatment of fever in stroke have been suggested, but reliable data are even more limited than for pharmacologic approaches (table 2). The studies described in what follows used either a fixed combination with acetaminophen $[26,27]$ or a standardized sequence of different antipyretic means arranged as a 'rescue' strategy in cases of treatment failure $[22,28]$. As effects may cumulate, results are not exclusively dedicated to the physical cooling method itself but may derive from additive or even superadditive effects of concomitant antipyretic medication.

In one study, air-circulating cooling blankets in combination with acetaminophen were not able to effectively reduce body temperature within $24 \mathrm{~h}$ in 113 patients compared to acetaminophen alone [26]. Water-circulating systems achieved a significant reduction in fever burden, but no data are available on functional outcome [27]. Two studies used intravascular devices for body temperature control: Diringer [28] treated 296 patients with fever $\left(>38.0^{\circ} \mathrm{C}\right)$ following a sequence of acetaminophen, ibuprofen, cooling blankets, gastric lavage and ice packs. 154 patients were randomized to additional endovascular cooling with a CoolGard catheter system for $72 \mathrm{~h}$, inserted through a central venous access. Broessner et al. [22] used long-term prophylactic, endovascular temperature control (Cool Line device set to a target temperature of $36.5^{\circ} \mathrm{C}$ and inserted into the subclavian vein) for up to 14 days after subarachnoid hemorrhage, intracerebral hemorrhage or ischemic stroke in addition to a 4 -step antipyretic regi- 
Table 2. Prospective randomized trials on combined (physical + pharmacologic) antipyretic regimens

\begin{tabular}{|c|c|c|c|c|c|c|c|c|c|}
\hline $\begin{array}{l}\text { Reference, } \\
\text { year }\end{array}$ & Interventions & $\mathrm{n}$ & Disease & $\begin{array}{l}\text { Number } \\
\text { of study } \\
\text { centers }\end{array}$ & $\begin{array}{l}\text { Qualifying } \\
\text { body tem-- } \\
\text { perature, }{ }^{\circ} \mathrm{C}\end{array}$ & $\begin{array}{l}\text { Duration } \\
\text { of treat- } \\
\text { ment, days }\end{array}$ & $\begin{array}{l}\text { Measure- } \\
\text { ment }\end{array}$ & Prim. EP & $\begin{array}{l}\text { Result } \\
\text { (Prim. EP) }\end{array}$ \\
\hline $\begin{array}{l}\text { Mayer } \\
\text { et al. [26], } \\
2001\end{array}$ & $\begin{array}{l}\text { cooling blanket (air-circulating) + } \\
\text { acetaminophen }\end{array}$ & 220 & $\begin{array}{l}\text { ICH, SAH, IS, } \\
\text { TBI and others }\end{array}$ & 1 & $\geq 38.3$ & 1 & tympanic & $\begin{array}{l}\text { normothermia } \\
\text { at } 24 \mathrm{~h}\end{array}$ & $\begin{array}{l}\text { negative } \\
35.5 \text { vs. } 44.2 \% \\
p=0.19\end{array}$ \\
\hline $\begin{array}{l}\text { Mayer } \\
\text { et al. [27], } \\
2004\end{array}$ & $\begin{array}{l}\text { cooling blanket (water-circulating) + } \\
\text { acetaminophen }\end{array}$ & 47 & $\begin{array}{l}\text { SAH, IS, ICH, } \\
\text { TBI }\end{array}$ & 1 & $\geq 38.3$ & 1 & tympanic & $\begin{array}{l}\text { fever burden } \\
\text { within } 24 \mathrm{~h}\end{array}$ & $\begin{array}{l}\text { positive } \\
4.1 \text { vs. } 16.1^{\circ} \mathrm{C} \\
\mathrm{p}=0.001\end{array}$ \\
\hline $\begin{array}{l}\text { Diringer } \\
{[28], 2004}\end{array}$ & $\begin{array}{l}\text { endovascular cooling + acetaminophen, } \\
\text { ibuprofen, cooling blanket, ice packs, } \\
\text { gastric lavage }\end{array}$ & 296 & TBI, ICH, IS & 13 & $>38.0$ & 3 & bladder & $\begin{array}{l}\text { fever burden } \\
\text { within } 72 \mathrm{~h}\end{array}$ & $\begin{array}{l}\text { positive } \\
2.87 \text { vs. } 7.92^{\circ} \mathrm{C} \\
\mathrm{p}<0.01\end{array}$ \\
\hline $\begin{array}{l}\text { Broessner } \\
\text { et al. [22], } \\
2009\end{array}$ & $\begin{array}{l}\text { endovascular cooling + acetaminophen, } \\
\text { ibuprofen, pethidine, cooling blanket }\end{array}$ & 102 & SAH, IS, ICH & 2 & $\geq 35.5$ & $7-14$ & bladder & $\begin{array}{l}\text { fever burden } \\
\text { (up to } \\
14 \text { days) }\end{array}$ & $\begin{array}{l}\text { positive } \\
0.0 \text { vs. } 4.3^{\circ} \mathrm{C} \\
\mathrm{p}<0.0001\end{array}$ \\
\hline
\end{tabular}

men including (1) acetaminophen, (2) ibuprofen, (3) pethidine, and (4) cooling blanket. Both catheter-based trials achieved an effective control of body temperature, but only one study investigated functional outcome after 6 months, which remained unaffected by the procedure.

In summary, the available data may allow the assertion that physical antipyretic strategies are feasible for critically ill stroke patients, but reliable data on their safety and efficacy beyond the ICU are lacking.

\section{Conclusions}

There is broad consensus that symptomatic fever treatment represents an elementary part of stroke care. Both pharmacologic and physical antipyretic methods are able to effectively lower body temperature. However, beneficial effects on clinical outcome await confirmation. Future work should concentrate on multimodal treatment protocols and more advanced methods of physical cooling, including endovascular techniques. A rigorous control of fever is the basic prerequisite of antipyretic treatment in order to achieve its translation to improved functional outcome.

\section{Evidence for the Influence of Induced Hypothermia in Stroke}

One major aim of stroke research is to identify neuroprotective agents or methods and transfer their potential to clinical trials. The term 'neuroprotection' means to pre- serve or save reversibly injured neurons from further damage and avoid cell death. As the knowledge about the pathophysiologic pathways after focal cerebral ischemia has increased, the number of agents that were neuroprotective in animal experiments rose [29]. Yet, none of these neuroprotective agents has proven to be effective in randomized controlled human trials. As neuroprotective treatments typically target one or more different interlinking mechanisms after ischemic brain damage, parallel pathways might be activated, or the optimal time window for treatment might be missed. Moreover, neuroprotective agents tend to preferably work in models of transient as compared to permanent ischemia. However, there are robust data that most occluded arteries recanalize more slowly in human [30]. Consequently, the combination of recanalization methods with concomitant neuroprotective agents can represent a successful approach.

At present, therapeutic hypothermia is being considered the most promising neuroprotective candidate for stroke. It incorporates all of the criteria of the Stroke Therapy Academic Industry Roundtable [31] and influences a number of pathophysiologic pathways after stroke. Moreover, hypothermia is already being used to improve neurological outcome and overall survival in comatose patients treated within $6 \mathrm{~h}$ after cardiac arrest $[13,14]$.

\section{Experimental Studies}

Experimental studies in different species as well as in vitro models indicate multiple modes of action after per- 
manent and transient cerebral ischemia [32]. Some of the major mechanisms are described as follows: hypothermia reduces the cerebral infarct size, edema formation and damage to the blood-brain barrier $[15,16]$. Moreover, it diminishes activation of microglia, production of oxygen free radicals, and the release of excitotoxic neurotransmitters as well as lactate and pyruvate. Besides, the cerebral metabolic rate, apoptosis and the local inflammatory response are reduced. There are important key messages arising from experimental data which are highlighted by representative studies below [33].

The results of therapeutic cooling in models of permanent focal cerebral ischemia are inconclusive. Some publications find no reduction of infarct volume using different methodology $[34,35]$. In contrast, profound hypothermia to $24^{\circ} \mathrm{C}$ for $6 \mathrm{~h}$ reduced the infarct volume by up to $84 \%$ [36] and even short periods of cooling (60 $\mathrm{min})$ at target temperatures between 30 and $34.5^{\circ} \mathrm{C}$ during $1 \mathrm{~h}$ of middle cerebral artery occlusion (MCAO) reduced the infarct volume by $60 \%$ [37]. Obviously, the time to treatment onset of hypothermia influences its effectiveness. For example, infarct reduction was apparent $6 \mathrm{~h}$ after MCAO, but it disappeared after $24 \mathrm{~h}$ [38]. In this study, hypothermia to $33^{\circ} \mathrm{C}$ was performed with a delay of $1 \mathrm{~h}$ and maintained for $5 \mathrm{~h}$. Results from animal experiments in transient cerebral ischemia models are more consistently positive than those evaluating permanent ischemia, and there is more clear evidence for neuroprotection. The majority of studies used goal temperatures between 30 and $33^{\circ} \mathrm{C}$ in models of $60-180 \mathrm{~min}$ of MCAO. Even after observation periods of 30 days, a reduction in infarct size of $51 \%$ was shown [39].

Hypothermia was more effective when started early after symptom onset. An animal study compared the use of intra- and postischemic hypothermia [40] and subjected the animals to $120 \mathrm{~min}$ of MCAO. Hypothermia to $33^{\circ} \mathrm{C}$ maintained for $120 \mathrm{~min}$ was started at ischemia onset or with a delay of 90,120 or $180 \mathrm{~min}$, and the animals were allowed to survive for $72 \mathrm{~h}$. Hypothermia delayed by 90 or 120 min resulted in higher survival und functional outcome compared to normothermia, but treatment after 180 min showed no measurable effect compared with the control group. Similar results appeared for the size of infarct. However, it was suggested that the delay of hypothermic therapy may be overcome by increasing the duration of cooling. One study showed that moderate hypothermia $\left(33^{\circ} \mathrm{C}\right)$ induced $1 \mathrm{~h}$ after transient MCAO $(120 \mathrm{~min})$ for a duration of $5 \mathrm{~h}$ led to persistent neuroprotection over a period of 5 days [41]. Yanamoto et al. [42] showed that hypothermia to $33^{\circ} \mathrm{C}$ started directly after reperfusion for
$24 \mathrm{~h}$ in a rodent model of 180 min of MCAO reduced infarct volume by $32 \%$ at $24 \mathrm{~h}$. In contrast, hypothermia to $32^{\circ} \mathrm{C}$ started after $120 \mathrm{~min}$ and maintained for $22 \mathrm{~h}$ did not reduce infarct volume after $2 \mathrm{~h}$ of MCAO [39].

In summary, available data demonstrate that hypothermia is more successful when applied in reperfusion models, but there are only a limited number of animal studies investigating the combination of recanalization therapy and hypothermia. Whether hypothermia could serve as a 'bridging therapy' for the time from symptom onset until recanalization, thereby preserving neuronal tissue until cerebral blood flow is re-established and reducing reperfusion-associated injury, has poorly been addressed so far. An early animal study did not demonstrate any additional effects of hypothermia $\left(32^{\circ} \mathrm{C}\right)$ compared to rt-PA treatment alone [43]. Potentially, the beneficial effects of cooling could have been overlooked in this study since thrombolysis alone led to very good functional outcome and small infarcts. Another study investigated the effects of hypothermia $\left(33^{\circ} \mathrm{C}\right)$ induced $1 \mathrm{~h}$ after thromboembolic occlusion of the middle cerebral artery [44]. Hypothermia reduced infarct volume and mortality compared to the control group and effects of thrombolysis were not affected by hypothermia as seen in perfusionweighted imaging, suggesting no serious side effects of cooling on rt-PA-induced recanalization in vivo. However, due to the relatively high mortality rate of the used model, other effects might have been missed [44].

Consequent comparison of different target temperatures is another rather unexplored topic. Most experimental studies compare normothermia to one or two different degrees of hypothermia $[45,46]$. However, results are inconsistent. While cooling to $34^{\circ} \mathrm{C}$ reduced infarct size by $60 \%$, there was no infarct visible at $29^{\circ} \mathrm{C}$ [47]. Huh et al. [45] showed $59 \%$ infarct reduction for $33^{\circ} \mathrm{C}$, but less reduction at $27^{\circ} \mathrm{C}$. In a recent study, different target temperatures were compared systematically [48]. Rats were subjected to 90 min of MCAO and kept at core temperatures of $37,36,35,34,33$, and $32^{\circ} \mathrm{C}$ over a period of $4 \mathrm{~h}$. Endpoints after $24 \mathrm{~h}$ and 5 days suggest a U-shaped curve of effectiveness of hypothermia, as temperatures of 34 and $33^{\circ} \mathrm{C}$ were superior to all others.

Rewarming is a critical aspect in hypothermia treatment. In a recent animal study, slow rewarming reduced infarct size and postischemic inflammation and improved neurological outcome compared to animals treated either with normothermia or with hypothermia and subsequent rapid rewarming [49].

Patients under hypothermia treatment often require mechanical ventilation, which itself may affect the clini- 
cal outcome. In principle, two different ventilation strategies are possible: during $\alpha$-stat management, arterial $\mathrm{CO}_{2}$ tension $\left(\mathrm{PaCO}_{2}\right)$ is maintained at $40 \mathrm{~mm} \mathrm{Hg}$ when measured at $37^{\circ} \mathrm{C}$. The dissociation fraction of the imidazole moiety of histidine is thereby constant, whereas $\mathrm{pH}$ changes parallel to the neutral point of water. In contrast, during $\mathrm{pH}$-stat management, $\mathrm{PaCO}_{2}$ is corrected to the patient's actual body temperature. Because of the increased gas solubility during hypothermia, the $\alpha$-stat strategy results in relative hyperventilation, which may affect cerebral blood flow. Concerning this critical topic, only one experimental study [50] and one clinical investigation in acute stroke [51] have been carried out. Surprisingly, there are no data available for patients with traumatic brain injury or cardiac arrest. In the experimental stroke study, $\mathrm{pH}$-stat management during early hypothermia reduced cerebral infarct volume in a suture occlusion model of focal cerebral ischemia compared to alpha-stat management [50]. As the suggested mechanisms may be improved cerebral blood flow in penumbral regions, a more consistent brain temperature and/or potential washout of excitotoxic neurotransmitters such as glutamate by increased cerebral blood flow, further investigations are necessary in this field.

\section{Conclusions and Limitations of Animal Stroke}

Studies on Induced Hypothermia

In summary, van der Worp et al. [12] elucidated that therapeutic hypothermia reduced infarct size by $44 \%$ (95\% CI 40-47). Efficacy was highest with reduction to lower temperatures $\left(31^{\circ} \mathrm{C}\right)$, when treatment was started before or at the onset of ischemia, and in temporary rather than permanent ischemia models. However, a reduction in infarct volume by about one third was also observed with a temperature reduction to $35^{\circ} \mathrm{C}$, with initiation of treatment between 90 and $180 \mathrm{~min}$, and in permanent ischemia models.

Besides the limitations of the stroke models themselves, major differences between the experimental and the clinical settings need to be considered when methods are transferred from bench to bedside.

- Despite many similarities, thermoregulation in rodents remains different from thermoregulation in human grown-up individuals (e.g. different ratio of body mass and surface). Therefore, hypothermia is induced and sustained comparatively easily in rodents by physical means, such as ice packs, intravenous fluids or even spontaneous hypothermia due to sedation. A more complex and invasive methodology is necessary when hypothermia is applied in human.
- Discomfort and vegetative regulatory mechanisms, such as cold shivering, are hard to assess in rodents, but represent essential limiting factors for clinical trials.

- Rodent models of space-occupying stroke are associated with high mortality, show difficulty in the assessment of functional deficits and may therefore be prone to selection and interpretation bias.

- Infections are one major complication of therapeutic hypothermia in humans. In preclinical studies, they are not assessed sufficiently, and adequate diagnostic and therapeutic strategies are not taken into account.

\section{Clinical Studies}

Despite the robust experimental data on the neuroprotective effects of induced hypothermia and its successful usage in patients after cardiac arrest, at present the number of clinical studies remains rather small. Questions of highest clinical relevance have not been addressed adequately yet, including the optimal target temperature, best method of cooling, rewarming approaches, optimal and sufficient treatment induction and duration as well as shivering control. In general, hypothermia is divided into severe hypothermia equaling a temperature below $28^{\circ} \mathrm{C}$, moderate hypothermia equaling $28-33^{\circ} \mathrm{C}$, and mild hypothermia equaling $33-36^{\circ} \mathrm{C}$. To date, the majority of studies has used mild or moderate hypothermia due to several reasons: with its degree, the incidence of major known side effects during hypothermia increases, including hypokalemia, cardiac rhythm and conduction disturbances, infectious complications and coagulopathy. Moreover, severe hypothermia requires sedation and mechanical ventilation, which in turn is associated with further adverse events and may impair a precise evaluation of neurological deficits.

In essence, clinical studies of induced hypothermia can be divided into two groups: those including patients who are sedated and mechanically ventilated and those including patients who receive therapeutic cooling while being awake. Tables 3 and 4 summarize the most important studies during the past 12 years.

\section{Therapeutic Cooling in Ventilated Patients}

One hundred patients with a large MCA stroke were treated by moderate hypothermia during sedation and mechanical ventilation [52-55]. All patients were cooled to a target temperature of $33^{\circ} \mathrm{C}$, measured by a bladder thermistor. Hypothermia was initiated between 4 and $24 \mathrm{~h}$ after symptom onset, and maintained for $48-72 \mathrm{~h}$. The mortality rate was $44 \%$ in the first of the study series 
Table 3. Prospective clinical trials on induced hypothermia in sedated stroke patients

\begin{tabular}{|c|c|c|c|c|c|c|c|c|c|c|}
\hline $\begin{array}{l}\text { Reference } \\
\text { year }\end{array}$ & $\begin{array}{l}\text { Dis- } \\
\text { ease }\end{array}$ & $\begin{array}{l}\text { Study } \\
\text { design }\end{array}$ & $\mathrm{n}$ & Method of cooling & $\begin{array}{l}\text { Target } \\
\text { tempera- } \\
\text { ture, }{ }^{\circ} \mathrm{C}\end{array}$ & $\begin{array}{l}\text { Time to } \\
\text { treatment onset } \\
\text { (mean } \pm \mathrm{SD}), \mathrm{h}\end{array}$ & $\begin{array}{l}\text { Treatment } \\
\text { duration } \\
\text { days }\end{array}$ & $\begin{array}{l}\text { ICP values } \\
\text { provided }\end{array}$ & $\begin{array}{l}\text { Mor- } \\
\text { tality } \\
\%\end{array}$ & $\begin{array}{l}\text { Functional } \\
\text { outcome at } \\
\text { day } 90\end{array}$ \\
\hline $\begin{array}{l}\text { Schwab } \\
\text { et al. [55], } 1998\end{array}$ & SIS & 2 & 25 & $\begin{array}{l}\text { cooling blankets, cold infusions, } \\
\text { cold washing }\end{array}$ & 33 & $14 \pm 7$ & $2-3$ & + & 48 & $\begin{array}{l}\text { mRS: } 2.6(2-4) \\
\text { SSS: } 38(28-48 \\
\text { BI: } 70(60-85)\end{array}$ \\
\hline $\begin{array}{l}\text { Schwab } \\
\text { et al. [54], } 2001\end{array}$ & SIS & 1 & 50 & $\begin{array}{l}\text { cooling blankets, alcohol packs, } \\
\text { ice bags }\end{array}$ & 33 & $22 \pm 9$ & $1-3$ & + & 38 & $\begin{array}{l}\text { mRS: } 2.9(2-5) \\
\text { BI: } 65(10-85)^{\mathrm{b}}\end{array}$ \\
\hline $\begin{array}{l}\text { Georgiadis } \\
\text { et al. [53], } 2001\end{array}$ & SIS & 1 & 6 & endovascular & 33 & $28 \pm 17$ & $2-3$ & - & $17^{\mathrm{a}}$ & - \\
\hline $\begin{array}{l}\text { Georgiadis } \\
\text { et al. [52], } 2002\end{array}$ & SIS & 3 & 19 & $\begin{array}{l}\text { cooling blankets + fanning }(\mathrm{n}=12) \\
\text { or endovascular }(\mathrm{n}=7)\end{array}$ & 33 & $24 \pm 6$ & $2-3$ & + & $47^{\mathrm{a}}$ & - \\
\hline $\begin{array}{l}\text { Krieger } \\
\text { et al. [57], } 2001\end{array}$ & SIS & 3 & 6 & $\begin{array}{l}\text { cooling blanket, iced water, } \\
\text { alcohol }\end{array}$ & $32 \pm 1$ & $6 \pm 1$ & $1-4$ & - & 33 & mRS: $3.1 \pm 2.3$ \\
\hline $\begin{array}{l}\text { Kollmar } \\
\text { et al. [58], } 2010\end{array}$ & $\mathrm{ICH}$ & 2 & 12 & endovascular & 35 & $3-12$ & 10 & + & 0 & mRS: $4.2 \pm 0.7$ \\
\hline
\end{tabular}

SIS = Severe ischemic stroke; ICH = intracerebral hemorrhage; ICP = intracranial pressure; SSS = Scandinavian Stroke Scale; BI = Barthel index; NIHSS $=$ National Institutes of Health Stroke Scale. Study design: 1 = no control group; $2=$ historical control group; $3=$ nonrandomized parallel control arm. $\mathrm{n}=$ Number of patients in the active treatment group. Mortality rate is given by day 90 except where otherwise indicated. Data for functional outcome are presented as mean values \pm standard deviation or range, except where otherwise indicated.

${ }^{\mathrm{a}}$ During acute phase. ${ }^{\mathrm{b}}$ Median (range).

Table 4. Prospective studies on induced hypothermia in awake patients with ischemic stroke

\begin{tabular}{|c|c|c|c|c|c|c|c|c|}
\hline Reference, year & $\begin{array}{l}\text { De- } \\
\text { sign }\end{array}$ & $\mathrm{n}$ & Method of cooling & $\begin{array}{l}\text { Target tem- } \\
\text { perature, }{ }^{\circ} \mathrm{C}\end{array}$ & $\begin{array}{l}\text { Time to treat- } \\
\text { ment onset, } \mathrm{h}\end{array}$ & $\begin{array}{l}\text { Treatment } \\
\text { duration, } \mathrm{h}\end{array}$ & $\begin{array}{l}\text { Mor- } \\
\text { tality, \% }\end{array}$ & Clinical outcome measures \\
\hline $\begin{array}{l}\text { Kammersgaard } \\
\text { et al. [60], } 2000\end{array}$ & 2 & 17 & $\begin{array}{l}\text { cooling blanket } \\
\text { (forced air method) }\end{array}$ & 35.5 & $3 \pm 4$ & 6 & $6^{c}$ & SSS at month 6 \\
\hline Knoll et al. [61], 2002 & 1 & 18 & $\begin{array}{l}\text { water-perfused } \\
\text { cooling mattress }\end{array}$ & $36-37$ & 26 & 24 & 12 & $\mathrm{BI}$ and $\mathrm{mRS}$ at day 90 \\
\hline De Georgia et al. [62], 2004 & 3 & 18 & endovascular & 33 & $9 \pm 3$ & 24 & 28 & NIHSS and $m R S$ at day 5 and day 30 \\
\hline Lyden et al. [63], 2005 & 1 & 18 & endovascular & 33 & $8 \pm 3$ & 24 & $17^{\mathrm{c}}$ & NIHSS, BI, mRS at discharge and day 30 \\
\hline Kollmar et al. [64], 2009 & 1 & 10 & ice-cold saline i.v. & - & $2 \pm 0.3$ & $3^{\mathrm{b}}$ & $0^{\mathrm{d}}$ & NIHSS at discharge \\
\hline Hemmen et al. [65], 2010 & 3 & 28 & endovascular & 33 & $5.9^{\mathrm{a}}$ & 24 & 21.4 & $\begin{array}{l}\text { NIHSS at } 24 \text { h, day } 30 \text { and day } 90 \text {; } \\
\text { mRS at day } 90\end{array}$ \\
\hline
\end{tabular}

$\mathrm{n}=$ Number of patients in the hypothermia group. Design: $1=$ no control group; 2 = historical control group; $3=$ prospective, randomized control group. SSS = Scandinavian Stroke Scale; BI = Barthel index; NIHSS = National Institutes of Health Stroke Scale. Mortality rate is given by day 90 except where otherwise indicated.

a Patients in the group 'hypothermia combined with thrombolysis'. ${ }^{\mathrm{b}}$ Treatment effect lasted for approximately $3 \mathrm{~h} .{ }^{\mathrm{c}}$ Mortality by 28 days. ${ }^{\mathrm{d}}$ During acute phase.

[55] compared to $78 \%$ in a historical standard treatment group [56]. Some of the survivors recovered to independence, indicated by a median Barthel index of 70 (range, $60-85$ ) and a mean mRS score of 2.6 (range, $2-4$ ). In these studies, therapeutic cooling was effective in controlling the intracranial pressure (ICP). However, a secondary rise of ICP, occasionally exceeding initial ICP levels and requiring additional treatment with osmotic therapy, was observed on rewarming in a significant number of patients. The rewarming period represented the most criti- 
cal phase for these patients, as all deaths were caused by treatment-refractory elevated ICP and subsequent herniation. Similar results were observed in a multicenter observational study, which reported results of 50 prospective patients with cerebral infarction involving the entire MCA territory and treated with mild hypothermia [54]. Overall mortality was $38 \%$, with $8 \%$ during hypothermia and $30 \%$ during rewarming, due to uncontrollable ICP increases. Neurological outcome was an average NIHSS score of 28 at 4 weeks and an mRS score of 2.9 at 3 months.

The limited data from nonrandomized trials on malignant MCA stroke treated by hypothermia are not sufficient at this point to recommend its routine use. Future trials might combine therapeutic cooling and decompressive surgery in order to add a neuroprotective method to effective ICP control. A small study in ventilated patients assessed moderate hypothermia in combination with thrombolysis in the ICU setting [57]. All patients were mechanically ventilated as part of the cooling procedure, which was initiated $6.2 \pm 1.3 \mathrm{~h}$ after stroke symptom onset. The time to the target core body temperature of $32 \pm 1^{\circ} \mathrm{C}$ was $3.5 \pm 1.5 \mathrm{~h}$ using cooling blankets, iced water, alcohol and whole-body ice rubs. Hypothermia was maintained for a period of $22.8 \pm 8 \mathrm{~h}$. The study suggested that hypothermia may be safe and feasible in this setting, but the patient number was too small to draw further conclusions. Recently first substantial data on the usage of hypothermia in patients with intracerebral hemorrhage were published [58], following early case series [59]. Twelve patients with intracerebral hemorrhage were treated with mild hypothermia to $35^{\circ} \mathrm{C}$, maintained by an endovascular device for 10 days. Hypothermia treatment effectively prevented the evolution of a perihemorrhagic edema in the active group, while patients of the historical control group showed a significant progression in edema volume over time. Prolonged hypothermia initiated within $12 \mathrm{~h}$ after symptom onset was a highly effective anti-edematous therapy, resulting in an excellent survival rate after 90 days (100\%). As in previous investigations, pneumonia was the mayor adverse event and affected all patients in the active group, but could be treated with antibiotics successfully in every case.

\section{Therapeutic Cooling in Awake Patients}

As mentioned before, major factors limit studies on hypothermia in patients under sedation and mechanical ventilation. These factors include limited ICU resources, invasiveness, respirator-associated infections and inability to reliably assess the neurological status. Since stroke units with adequate conditions for close monitoring be- came an integral part of care, large studies in awake patients may be a promising approach for the future. So far, the number of studies on nonsedated patients has been limited. Kammersgaard et al. [60] published a prospective study, in which 17 patients with induced hypothermia were compared to 56 control patients. The therapy was restricted to only $6 \mathrm{~h}$ and used cooling blankets. Compensatory shivering was treated by administration of 25-50 mg of pethidine. This approach lowered the body temperature from 36.8 to $35.5^{\circ} \mathrm{C}$ during treatment. The study was not powered to investigate differences in mortality or functional outcome, although a trend towards lower mortality for the hypothermia group was evident. Another study performed by Knoll et al. [61] may be regarded as connecting antipyretic treatment and induced hypothermia: body temperature was maintained between 36 and $37^{\circ} \mathrm{C}$ for $24 \mathrm{~h}$ in 18 patients, who were laid on a water-perfused cooling mattress and treated with pethidine and dihydroergotoxine. Target temperature was achieved in all but 2 patients and no major side effects were described. In the COOL AID II study, de Georgia et al. [62] for the first time used endovascular cooling methods to induce and maintain mild hypothermia over $24 \mathrm{~h}$ in 18 awake patients. MRI data indicated less lesion growth with hypothermia compared to 22 normothermic patients under standard medical management. Thirteen patients reached the target temperature after a mean of $77 \pm 44 \mathrm{~min}$ and hypothermia was well tolerated in most patients. Clinical outcomes were similar in both groups. Lyden et al. [63] performed the Intravascular Cooling in the Treatment of Stroke study, in which meperidine and buspirone were used to prevent and counteract shivering. One particular challenge for hypothermia treatment in acute stroke is its combination with recanalization strategies. Up to date, three studies have addressed this issue in awake patients: a pilot study investigated 10 participants with acute stroke, presenting within a 3-hour time window [64]. Intravenous infusion of ice-cold saline was used for the induction of hypothermia (20 ml/kg body weight) shortly after the initial CT scan (in 9 of 10 patients during the thrombolytic therapy). This method was feasible and safe for awake patients in the emergency setting. Shivering was treated and prevented by the use of pethidine and buspirone. The tympanic temperature decreased within $60 \mathrm{~min}$ by an average of $1.7^{\circ} \mathrm{C}$ and remained below $36^{\circ} \mathrm{C}$ for $3 \mathrm{~h}$. Another approach combined intravenous thrombolysis in acute stroke with endovascular cooling in 10 patients. A minimum time period of $30 \mathrm{~min}$ was allowed to elapse after rt-PA infusion, until catheter insertion procedures were 
Table 5. Rate of pneumonia and cardiac arrhythmia (supra- and ventricular arrhythmia except asymptomatic bradycardia) during hypothermia treatment

\begin{tabular}{lcl}
\hline Reference, year & $\begin{array}{l}\text { Rate of } \\
\text { pneumonia } \\
\%\end{array}$ & $\begin{array}{l}\text { Significant } \\
\text { cardiac } \\
\text { arrhythmia, \% }\end{array}$ \\
& $\begin{array}{l}\text { aric stroke } \\
\text { Sedated patients with severe hemispheric }\end{array}$ \\
Schwab et al. [55], 1998 & 40 & 60 \\
Schwab et al. [54], 2001 & 48 & 62 \\
Georgiadis et al. [53], 2001 & 100 & 50 \\
Georgiadis et al. [52], 2002 & 78 & 42 \\
Krieger et al. [57], 2001 & 40 & 33 \\
Sedated patients with intracerebral hemorrhage & \\
Kollmar et al. [58], 2010 & 100 & 0 \\
Awake patients with ischemic stroke & n.p. & 0 \\
Kammersgaard et al. [60], 2000 & 11 & 0 \\
Knoll et al. [61], 2002 & 0 & 17 \\
De Giorgia et al. [62], 2004 & 28 & 11 \\
Lyden et al. [63], 2005 & 50 & n.p. \\
Hemmen et al. [65], 2010 & & \\
\hline n.p. = Not provided. & & \\
\hline
\end{tabular}

initiated. A precise decrease in the core temperature was achieved by this method and shivering was successfully suppressed by buspirone, meperidine and cutaneous warming with a heating blanket. Recently the final data from a prospective controlled trial became available: the Intravascular Cooling in the Treatment of Stroke study investigated the feasibility and safety of hypothermia in combination with intravenous thrombolysis in a multicenter setting [65]. Forty-four patients were enrolled within $3 \mathrm{~h}$ and 14 patients between 3 and $6 \mathrm{~h}$ after symptom onset. Intravenous thrombolysis was performed in all patients presenting within the early time window and in $29 \%$ of cases presenting within the expanded time window. Twenty-eight patients were randomized to endovascular-based hypothermia. The insertion of the catheter began 30-180 min after completion of the rt-PA infusion and the time until achievement of the target temperature $\left(33^{\circ} \mathrm{C}\right)$ following catheter placement was $138 \pm 198 \mathrm{~min}$. In 2 patients, treatment failed due to technical difficulties. After 3 months, no significant differences were found in the number of patients with an mRS score of 0 or 1 in the active group compared to standard treatment. Pneumonia occurred more frequently in patients under hypothermia (50 vs. $10 \%$ ) but did not significantly affect functional outcome after 3 months. A total of 4 patients suffered symptomatic intracranial hemorrhage, and 1 of them had received treatment with hypothermia. However, these findings are not yet sufficient to draw sound conclusions on efficacy and await confirmation in future trials.

\section{Research Questions}

(1) Target temperature: the optimal target temperature remains to be determined. Large clinical studies are going to concentrate on 35 or $33^{\circ} \mathrm{C}$. Given the experimental and preliminary clinical experiences at present, this range may be an adequate choice. Results from different trials with analogue design will enable a comparison.

(2) Duration of hypothermia: at present, the most reliable data for successful hypothermia treatment after acute brain injury arise from the cardiac arrest trials [13, 14]. In analogy, the 12- to 24 -hour treatment duration might be appropriate for the translation to stroke patients. However, a surrogate parameter for neuronal damage, such as serum biomarkers or lesion growth on MRI, might be of major importance. It will assist in valid 'dose finding' and either favor adjustment of target temperature or hypothermia duration in case of treatment failure.

(3) Ventilation mode during hypothermia: in mechanically ventilated patients, $\alpha$-stat or $\mathrm{pH}$-stat mode can be used. Both techniques exert an influence on cerebral blood flow [50,51]. Future studies in mechanically ventilated patients should at least predefine and control the ventilation modes since this might be of high relevance for penumbral regions and ICP.

(4) Hypothermia and thrombolysis: preclinical data clearly show that hypothermia is far more effective in transient than in permanent ischemia $[12,33]$. Therefore, the combination of recanalization therapies (especially intravenous thrombolysis) with hypothermia is an urgent research topic. In vitro experiments describe a decrease in enzymatic activity of rt-PA by $2-4 \%$ during hypothermia to $30-33^{\circ} \mathrm{C}[66]$. However, latest clinical studies suggest feasibility and safety of the combination, but results are preliminary and await confirmation in future trials [64-67].

(5) Techniques for temperature control: external or internal cooling represent the major oppositional approaches [68]. So far, there is uncertainty as to the optimal method for temperature induction and control. It remains questionable whether external cooling is sufficient and tolerable for awake patients. On the other hand, endovascular approaches are characterized by invasiveness and complex handling in the emergency situation. Cur- 
rently, novel techniques, such as nasopharyngeal cooling devices, are under evaluation. A fast and easy approach for induction of hypothermia is the intravenous rapid infusion of cold saline [64], which is easy to use, cheap, and mostly well tolerated in awake patients. However, safety, and effectiveness of cold infusions need further assessment in clinical trials.

(6) Antishivering treatment: different pharmacologic approaches, such as meperidine and buspirone have shown to be effective for treatment of shivering [69] in awake stroke patients. However, opioids have severe side effects, including sedation, nausea and vomiting. This may cause discomfort to the patient, limit the tolerability of cooling and increase the risk for aspiration. Further research should address different antishivering protocols and re-evaluate the current concepts.

(7) Infections: one major side effect, observed repeatedly in previous trials, was an increase in infectious complications during hypothermia treatment, first of all pneumonia (table 5). Up to date, the pathogenesis of these complications has been poorly understood. It may be speculated that the known immunosuppressive effects of stroke itself [70] interact with hypothermia treatment and the combination of both increases the susceptibility to infectious agents. One adequate therapeutic approach could be the prophylactic antibiotic treatment during hypothermia, as already suggested for acute stroke in previous trials $[71,72]$.

\section{Conclusions}

The data available at present do not yet justify the routine use of hypothermia treatment for unselected stroke patients outside of clinical trials. Effective cooling techniques are feasible to induce and maintain stable systemic hypothermia. However, the efficacy of this approach on functional outcome requires confirmation by large, controlled trials. Further important issues need to be addressed by these investigations, including the duration and depth of hypothermia, choice of optimal cooling methodology, as well as adequate handling of complications, infections and shivering.

\section{References}

1 Kolominsky-Rabas PL, Heuschmann PU, Marschall D, Emmert M, Baltzer N, Neundorfer B, Schoffski O, Krobot KJ: Lifetime cost of ischemic stroke in Germany: results and national projections from a populationbased stroke registry: the Erlangen Stroke Project. Stroke 2006;37:1179-1183.

2 Sandercock PA, Counsell C, Gubitz GJ, Tseng MC: Antiplatelet therapy for acute ischaemic stroke. Cochrane Database Syst Rev 2008;3:CD000029.

-3 Hacke W, Donnan G, Fieschi C, Kaste M, von Kummer R, Broderick JP, Brott T, Frankel M, Grotta JC, Haley EC, Jr., Kwiatkowski T, Levine SR, Lewandowski C, Lu M, Lyden P, Marler JR, Patel S, Tilley BC, Albers G, Bluhmki E, Wilhelm M, Hamilton S: Association of outcome with early stroke treatment: pooled analysis of ATLANTIS, ECASS, and NINDS rt-PA stroke trials. Lancet 2004;363:768-774.

4 Hacke W, Kaste M, Bluhmki E, Brozman M, Davalos A, Guidetti D, Larrue V, Lees KR, Medeghri Z, Machnig T, Schneider D, von Kummer R, Wahlgren N, Toni D: Thrombolysis with alteplase 3 to $4.5 \mathrm{~h}$ after acute ischemic stroke. N Engl J Med 2008;359:13171329.

5 Furlan A, Higashida R, Wechsler L, Gent M, Rowley H, Kase C, Pessin M, Ahuja A, Callahan F, Clark WM, Silver F, Rivera F: Intra- arterial prourokinase for acute ischemic stroke. The PROACT II study: a randomized controlled trial. Prolyse in Acute Cerebral Thromboembolism. JAMA 1999;282:20032011.

-6 Becker KJ, Brott TG: Approval of the MERCI clot retriever: a critical view. Stroke 2005;36 400-403.

7 Bose A, Henkes H, Alfke K, Reith W, Mayer TE, Berlis A, Branca V, Sit SP: The Penumbra System: a mechanical device for the treatment of acute stroke due to thromboembolism. AJNR Am J Neuroradiol 2008;29:1409_ 1413.

-8 Adams HP Jr, del Zoppo G, Alberts MJ, Bhatt DL, Brass L, Furlan A, Grubb RL, Higashida RT, Jauch EC, Kidwell C, Lyden PD, Morgenstern LB, Qureshi AI, Rosenwasser RH, Scott PA, Wijdicks EF: Guidelines for the early management of adults with ischemic stroke: a guideline from the American Heart Association/American Stroke Association Stroke Council, Clinical Cardiology Council, Cardiovascular Radiology and Intervention Council, and the Atherosclerotic Peripheral Vascular Disease and Quality of Care Outcomes in Research Interdisciplinary Working Groups: the American Academy of Neurology affirms the value of this guideline as an educational tool for neurologists. Circulation 2007;115:e478-e534. $\checkmark 9$ European Stroke Organization (ESO) Executive Committee and the ESO Writing Committee: Guidelines for management of ischemic stroke and transient ischemic attack 2008. Cerebrovasc Dis 2008;25:457-507.

10 Greer DM, Funk SE, Reaven NL, Ouzounelli M, Uman GC: Impact of fever on outcome in patients with stroke and neurologic injury: a comprehensive meta-analysis. Stroke 2008; 39:3029-3035.

11 Hajat C, Hajat S, Sharma P: Effects of poststroke pyrexia on stroke outcome: a metaanalysis of studies in patients. Stroke 2000; 31:410-414

12 van der Worp HB, Sena ES, Donnan GA, Howells DW, Macleod MR: Hypothermia in animal models of acute ischaemic stroke: a systematic review and meta-analysis. Brain 2007;130:3063-3074.

13 Mild therapeutic hypothermia to improve the neurologic outcome after cardiac arrest. N Engl J Med 2002;346:549-556.

14 Bernard SA, Gray TW, Buist MD, Jones BM, Silvester W, Gutteridge G, Smith K: Treatment of comatose survivors of out-of-hospital cardiac arrest with induced hypothermia. N Engl J Med 2002;346:557-563.

15 Dietrich WD, Atkins CM, Bramlett HM: Protection in animal models of brain and spinal cord injury with mild to moderate hypothermia. J Neurotrauma 2009;26:301-312. 
-16 MacLellan CL, Clark DL, Silasi G, Colbourne F: Use of prolonged hypothermia to treat ischemic and hemorrhagic stroke. J Neurotrauma 2009;26:313-323.

17 Baena RC, Busto R, Dietrich WD, Globus MY, Ginsberg MD: Hyperthermia delayed by $24 \mathrm{~h}$ aggravates neuronal damage in rat hippocampus following global ischemia. Neurology 1997;48:768-773.

18 Ginsberg MD, Busto R: Combating hyperthermia in acute stroke: a significant clinical concern. Stroke 1998;29:529-534.

19 Coimbra C, Drake M, Boris-Moller F, Wieloch T: Long-lasting neuroprotective effect of postischemic hypothermia and treatment with an anti-inflammatory/antipyretic drug. Evidence for chronic encephalopathic processes following ischemia. Stroke 1996; 27:1578-1585.

20 Den Hertog HM, van der Worp HB, Tseng MC, Dippel DW: Cooling therapy for acute stroke. Cochrane Database Syst Rev 2009; 1:CD001247.

21 den Hertog HM, van der Worp HB, van Gemert HM, Algra A, Kappelle LJ, van Gijn J, Koudstaal PJ, Dippel DW: The Paracetamol (Acetaminophen) In Stroke (PAIS) trial: a multicentre, randomised, placebo-controlled, phase III trial. Lancet Neurol 2009;8: 434-440.

- 22 Broessner G, Beer R, Lackner P, Helbok R, Fischer M, Pfausler B, Rhorer J, KuppersTiedt L, Schneider D, Schmutzhard E: Prophylactic, endovascularly based, long-term normothermia in ICU patients with severe cerebrovascular disease: bicenter prospective, randomized trial. Stroke 2009;40:e657e665.

-23 Dippel DW, van Breda EJ, van Gemert HM, van der Worp HB, Meijer RJ, Kappelle LJ, Koudstaal PJ: Effect of paracetamol (acetaminophen) on body temperature in acute ischemic stroke: a double-blind, randomized phase II clinical trial. Stroke 2001;32:16071612.

24 Koennecke HC, Leistner S: Prophylactic antipyretic treatment with acetaminophen in acute ischemic stroke: a pilot study. Neurology 2001;57:2301-2303.

25 Dippel DW, van Breda EJ, van der Worp HB, van Gemert HM, Meijer RJ, Kappelle LJ, Koudstaal PJ: Effect of paracetamol (acetaminophen) and ibuprofen on body temperature in acute ischemic stroke PISA, a phase II double-blind, randomized, placebo-controlled trial [ISRCTN98608690]. BMC Cardiovasc Disord 2003;3:2.

26 Mayer S, Commichau C, Scarmeas N, Presciutti M, Bates J, Copeland D: Clinical trial of an air-circulating cooling blanket for fever control in critically ill neurologic patients. Neurology 2001;56:292-298.

-27 Mayer SA, Kowalski RG, Presciutti M, Ostapkovich ND, McGann E, Fitzsimmons BF, Yavagal DR, Du YE, Naidech AM, Janjua
NA, Claassen J, Kreiter KT, Parra A, Commichau C: Clinical trial of a novel surface cooling system for fever control in neurocritical care patients. Crit Care Med 2004;32: 2508-2515.

28 Diringer MN: Treatment of fever in the neurologic intensive care unit with a catheterbased heat exchange system. Crit Care Med 2004;32:559-564.

29 O'Collins VE, Macleod MR, Donnan GA, Horky LL, van der Worp BH, Howells DW: 1,026 experimental treatments in acute stroke. Ann Neurol 2006;59:467-477.

30 Molina CA, Montaner J, Abilleira S, Arenillas JF, Ribo M, Huertas R, Romero F, Alvarez-Sabin J: Time course of tissue plasminogen activator-induced recanalization in acute cardioembolic stroke: a case-control study. Stroke 2001;32:2821-2827.

-31 Fisher M, Feuerstein G, Howells DW, Hurn PD, Kent TA, Savitz SI, Lo EH: Update of the stroke therapy academic industry roundtable preclinical recommendations. Stroke 2009;40:2244-2250.

32 Miyazawa T, Tamura A, Fukui S, Hossmann KA: Effect of mild hypothermia on focal cerebral ischemia. Review of experimental studies. Neurol Res 2003;25:457-464.

33 Kollmar R, Schwab S: Hypothermia in focal ischemia: implications of experiments and experience. J Neurotrauma 2009;26:377386.

34 Morikawa E, Ginsberg MD, Dietrich WD, Duncan RC, Kraydieh S, Globus MY, Busto $\mathrm{R}$ : The significance of brain temperature in focal cerebral ischemia: histopathological consequences of middle cerebral artery occlusion in the rat. J Cereb Blood Flow Metab 1992;12:380-389.

35 Ridenour TR, Warner DS, Todd MM, McAllister AC: Mild hypothermia reduces infarct size resulting from temporary but not permanent focal ischemia in rats. Stroke 1992; 23:733-738.

- 36 Baker CJ, Onesti ST, Barth KN, Prestigiacomo CJ, Solomon RA: Hypothermic protection following middle cerebral artery occlusion in the rat. Surg Neurol 1991;36:175-180.

- 37 Kader A, Brisman MH, Maraire N, Huh JT, Solomon RA: The effect of mild hypothermia on permanent focal ischemia in the rat. Neurosurgery 1992;31:1056-1060, discussion 1060-1061.

- 38 Doerfler A, Schwab S, Hoffmann TT, Engelhorn T, Forsting M: Combination of decompressive craniectomy and mild hypothermia ameliorates infarction volume after permanent focal ischemia in rats. Stroke 2001;32: 2675-2681.

39 Yanamoto H, Nagata I, Nakahara I, Tohnai N, Zhang Z, Kikuchi H: Combination of intraischemic and postischemic hypothermia provides potent and persistent neuroprotection against temporary focal ischemia in rats. Stroke 1999;30:2720-2726, discussion 2726.
40 Maier CM, Sun GH, Kunis D, Yenari MA, Steinberg GK: Delayed induction and longterm effects of mild hypothermia in a focal model of transient cerebral ischemia: neurological outcome and infarct size. J Neurosurg 2001;94:90-96.

41 Kollmar R, Schabitz WR, Heiland S, Georgiadis D, Schellinger PD, Bardutzky J, Schwab S: Neuroprotective effect of delayed moderate hypothermia after focal cerebral ischemia: an MRI study. Stroke 2002;33: 1899-1904.

42 Yanamoto H, Hong SC, Soleau S, Kassell NF, Lee KS: Mild postischemic hypothermia limits cerebral injury following transient focal ischemia in rat neocortex. Brain Res 1996;718:207-211.

43 Meden P, Overgaard K, Pedersen H, Boysen G: Effect of hypothermia and delayed thrombolysis in a rat embolic stroke model. Acta Neurol Scand 1994;90:91-98.

-44 Kollmar R, Henninger N, Bardutzky J, Schellinger PD, Schabitz WR, Schwab S: Combination therapy of moderate hypothermia and thrombolysis in experimental thromboembolic stroke - An MRI study. Exp Neurol 2004;190:204-212.

45 Huh PW, Belayev L, Zhao W, Koch S, Busto $\mathrm{R}$, Ginsberg MD: Comparative neuroprotective efficacy of prolonged moderate intraischemic and postischemic hypothermia in focal cerebral ischemia. J Neurosurg 2000; 92:91-99.

46 Maier CM, Ahern K, Cheng ML, Lee JE, Yenari MA, Steinberg GK: Optimal depth and duration of mild hypothermia in a focal model of transient cerebral ischemia: effects on neurologic outcome, infarct size, apoptosis, and inflammation. Stroke 1998;29:21712180.

47 Barone FC, Feuerstein GZ, White RF: Brain cooling during transient focal ischemia provides complete neuroprotection. Neurosci Biobehav Rev 1997;21:31-44.

- 48 Kollmar R, Blank T, Han JL, Georgiadis D, Schwab S: Different degrees of hypothermia after experimental stroke: short- and longterm outcome. Stroke 2007;38:1585-1589.

- 49 Berger C, Xia F, Kohrmann M, Schwab S: Hypothermia in acute stroke - Slow versus fast rewarming an experimental study in rats. Exp Neurol 2007;204:131-137.

- 50 Kollmar R, Frietsch T, Georgiadis D, Schabitz WR, Waschke KF, Kuschinsky W, Schwab S: Early effects of acid-base management during hypothermia on cerebral infarct volume, edema, and cerebral blood flow in acute focal cerebral ischemia in rats. Anesthesiology 2002;97:868-874.

51 Kollmar R, Georgiadis D, Schwab S: Alphastat versus ph-stat guided ventilation in patients with large ischemic stroke treated by hypothermia. Neurocrit Care 2009;10:173180 . 
-52 Georgiadis D, Schwarz S, Aschoff A, Schwab $S$ : Hemicraniectomy and moderate hypothermia in patients with severe ischemic stroke. Stroke 2002;33:1584-1588.

53 Georgiadis D, Schwarz S, Kollmar R, Schwab S: Endovascular cooling for moderate hypothermia in patients with acute stroke: first results of a novel approach. Stroke 2001;32: 2550-2553.

54 Schwab S, Georgiadis D, Berrouschot J, Schellinger PD, Graffagnino C, Mayer SA: Feasibility and safety of moderate hypothermia after massive hemispheric infarction. Stroke 2001;32:2033-2035.

55 Schwab S, Schwarz S, Spranger M, Keller E, Bertram M, Hacke W: Moderate hypothermia in the treatment of patients with severe middle cerebral artery infarction. Stroke 1998;29:2461-2466.

56 Hacke W, Schwab S, Horn M, Spranger M, De Georgia M, von Kummer R: 'malignant' middle cerebral artery territory infarction: clinical course and prognostic signs. Arch Neurol 1996;53:309-315.

-57 Krieger DW, De Georgia MA, Abou-Chebl A, Andrefsky JC, Sila CA, Katzan IL, Mayberg MR, Furlan AJ: Cooling for acute ischemic brain damage (cool aid): an open pilot study of induced hypothermia in acute ischemic stroke. Stroke 2001;32:1847-1854.

58 Kollmar R, Staykov D, Dorfler A, Schellinger $\mathrm{PD}$, Schwab S, Bardutzky J: Hypothermia reduces perihemorrhagic edema after intracerebral hemorrhage. Stroke 2010;41:16841689.

-59 Feng H, Shi D, Wang D, Xin X, Feng L, Zhang Y, Liu B: Effect of local mild hypothermia on treatment of acute intracerebral hemorrhage: a clinical study. Zhonghua Yi Xue Za Zhi 2002;82:1622-1624.
-60 Kammersgaard LP, Rasmussen BH, Jorgensen HS, Reith J, Weber U, Olsen TS: Feasibility and safety of inducing modest hypothermia in awake patients with acute stroke through surface cooling: a case-control study. The Copenhagen Stroke Study. Stroke 2000;31:2251-2256.

61 Knoll T, Wimmer ML, Gumpinger F, Haberl RL: The low normothermia concept - Maintaining a core body temperature between 36 and 37 degrees $C$ in acute stroke unit patients. J Neurosurg Anesthesiol 2002;14: 304-308.

-62 De Georgia MA, Krieger DW, Abou-Chebl A, Devlin TG, Jauss M, Davis SM, Koroshetz WJ, Rordorf G, Warach S: Cooling for acute ischemic brain damage (cool aid): a feasibility trial of endovascular cooling. Neurology 2004;63:312-317.

63 Lyden PD, Allgren RL, Ng K, Akins P, Meyer B, Al-Sanani F, Lutsep H, Dobak J, Matsubara BS, Zivin J: Intravascular cooling in the treatment of stroke (ICTuS): early clinical experience. J Stroke Cerebrovasc Dis 2005, 14:107-114.

64 Kollmar R, Schellinger PD, Steigleder T, Kohrmann M, Schwab S: Ice-cold saline for the induction of mild hypothermia in patients with acute ischemic stroke: a pilot study. Stroke 2009;40:1907-1909.

65 Hemmen TM, Raman R, Guluma KZ, Meyer BC, Gomes JA, Cruz-Flores S, Wijman CA, Rapp KS, Grotta JC, Lyden PD: Intravenous thrombolysis plus hypothermia for acute treatment of ischemic stroke (ICTuS-L). Final results. Stroke 2010;41:2265-2270.
66 Yenari MA, Palmer JT, Bracci PM, Steinberg GK: Thrombolysis with tissue plasminogen activator (tPA) is temperature dependent. Thromb Res 1995;77:475-481.

67 Guluma KZ, Hemmen TM, Olsen SE, Rapp KS, Lyden PD: A trial of therapeutic hypothermia via endovascular approach in awake patients with acute ischemic stroke: methodology. Acad Emerg Med 2006;13:820-827.

68 Jordan JD, Carhuapoma JR: Hypothermia: comparing technology. J Neurol Sci 2007; 261:35-38.

69 Mokhtarani M, Mahgoub AN, Morioka N, Doufas AG, Dae M, Shaughnessy TE, Bjorksten AR, Sessler DI: Buspirone and meperidine synergistically reduce the shivering threshold. Anesth Analg 2001;93:1233-1239.

70 Dirnagl U, Klehmet J, Braun JS, Harms H, Meisel C, Ziemssen T, Prass K, Meisel A: Stroke-induced immunodepression: experimental evidence and clinical relevance. Stroke 2007;38:770-773.

71 Harms H, Prass K, Meisel C, Klehmet J, Rogge W, Drenckhahn C, Gohler J, Bereswill S, Gobel U, Wernecke KD, Wolf T, Arnold G, Halle E, Volk HD, Dirnagl U, Meisel A: Preventive antibacterial therapy in acute ischemic stroke: a randomized controlled trial. PLoS One 2008;3:e2158.

72 Schwarz S, Al-Shajlawi F, Sick C, Meairs S, Hennerici MG: Effects of prophylactic antibiotic therapy with mezlocillin plus sulbactam on the incidence and height of fever after severe acute ischemic stroke: The Mannheim infection in stroke study (MISS). Stroke 2008;39:1220-1227.

-73 Kasner SE, Wein T, Piriyawat P, Villar-Cordova CE, Chalela JA, Krieger DW, Morgenstern LB, Kimmel SE, Grotta JC: Acetaminophen for altering body temperature in acute stroke: a randomized clinical trial. Stroke 2002;33:130-134 